\title{
EXPRESSION
}

\section{Simulative and esoteric aspects of pornography}

\author{
Jacek Gulanowski \\ jacek.gulanowski@gmail.com
}

\begin{abstract}
N. Wolf, a third wave feminist, in her controversial essay The Porn Myth discusses the question of switching previously taken positions: pornography has become a model for sex and sex the reflection of pornography. She sees the coming of the Internet and the adjustment of pornography to this medium as the root of the aforementioned transition. Contemporary pornography is a point where the works of postmodernists (especially J. Baudrillard and his theory of simulation and simulacra) and the pessimistic historiosophy of traditionalists and conservatives (particularly J. Evola and J. R. R. Tolkien). Meet focusing on the achievements of the postmodern world and traditional spirituality researchers can be very useful in portraying this complex and controversial phenomenon.
\end{abstract}

Keywords: pornography, sex, simulation, simulacrum, esotericism, symbol, religion, mythology, postmodernism, internet.

W. Godzic, one of the leading Polish researchers of popular culture, claims that in reference to contemporary audiovisual culture the role of a critic of these phenomena is no longer the creating of new interpretations but rather an attempt at understanding and comprehending many interpretations circulating throughout various discourses. And that, according to $\mathrm{W}$. Godzic, seems to be one of the toughest challenges which stand before the researchers of popular culture (Godzic 1996, p. 222). This paper is an attempt at meeting the aforementioned challenge in reference to an uncommonly complex and controversial phenomenon of postmodern popular culture: pornography. It is an effort to combine the achievements of two apparently mutually exclusive - postmodern and traditionalist.

\section{Simulative character of postmodern pornography}


Pornography as a phenomenon connected with both sex and gender has been an object of interest of feminism. N. Wolf, a third wave feminist, focused on this issue in her prominent essay The Porn Myth ${ }^{1}$. She criticizes the arguments of those who claimed that pornography would liberate people and heal their lives as well as the opponents of this phenomenon, who believed that pornography would increase aggression in the field of interpersonal relations.

According to N. Wolf the whole post-Internet world has become pornographized. "Young men and women are indeed being taught what sex is, how it looks, what its etiquette and expectations are, by pornographic training - and this is having a huge effect on how they interact". Pornography has deadened men's libido and made men to be no longer aroused by real women, whom they see as not "porn-worthy" (Wolf 2003, p. 1). N. Wolf claims that "the ubiquity of sexual images does not free eros but dilutes it". Furthermore, "people are not closer because of porn but further apart; people are not more turned on in their daily lives but less so". The author praises traditional cultures for a better understanding of human sexuality and for being able to bring closer together two people bound by marriage through the regulation of erotic images. N. Wolf criticizes feminists, as well, who in the course of the struggle against women's oppression have also rejected the positive aspects of the past. She sees a return to the old customs and detachment from pornography as a right way of overcoming this crisis: "the reason to turn off the porn might become, to thoughtful people, not a moral one but, in a way, a physical- and emotional-health one; you might want to rethink your constant access to porn in the same way that, if you want to be an athlete, you rethink your smoking" (Wolf 2003, p.2).

The importance of pornography is also noticed by A. Yawar, who in the essay The End Of Sex? specifies five changes which pornography has introduced into sex. According to him:

- pornography "has seeped into the rest of popular culture, significantly altering how people think about sex";

- "pornography has made sex more violent";

- pornography has changed women's self-perception and made them insecure about some of the most essential parts of their being;

- "sex has been sped up beyond all recognition", sexual foreplay is becoming abandoned;

- there is much less real sex than before, people are becoming bored with it, some turn asexual (Yawar 2006).

\footnotetext{
${ }^{1}$ This essay has been originally published in the "New York" magazine on 20.10.2003.
} 
However, uppermost for further deliberations is N. Wolf's remark that pornography, through the Internet, has become an omnipresent model for sex. Sex has become the reflection of pornography - not pornography the reflection of sex. As N. Wolf claims: "for most of human history, erotic images have been reflections of, or celebrations of, or substitutes for, real naked women. For the first time in human history, the images' power and allure have supplanted that of real naked women. Today, real naked women are just bad porn" (Wolf 2003, p. 1).

Therefore what has occurred is not only the separation of pornography and sex, but also expulsion of sex by pornography. Thus, the noteworthy issue is not the question of emancipation of sex through pornography, but the emancipation of pornography as a medium. Two turning points can be determined in this case, with their effects currently interacting- the first one is the abandonment of perceiving pornography as shameful and embarrassing; the second - the coming of the Internet age.

When analyzing the phenomenon of the "Playboy" magazine, K. T. Toeplitz ${ }^{2}$ points out the fact that this periodical managed to shift eroticism from a shameful and private area to publicly and commonly accepted entertainment. It was the first interchangeably erotic periodical that was not sold under the counter, like the Tijuana Bibles, and was not read secretly. "Playboy" published interviews and articles covering people famous in the mainstream press. It became a magazine read and discussed by people of various social backgrounds. "Playboy" has introduced eroticism into the mainstream (Toeplitz 1975, pp. 86125).

Pornography's coming out, the departure from the private and shameful area, has consequences for literary and scientific attempts at covering this phenomenon. People engaged in creating pornography no longer claim that they are occupied with just entertainment or art - that is: something completely different from porn - they consider themselves creators of pornographic entertainment or art. This assumption can help in overcoming the definitional disputes which arise when one attempts to discuss various aspects of pornography. Instead of stating what pornography is, searching for determinants, borderlines and models, one can rely on the self-identification of people involved in the making of pornography. Pornographic materials bear such a name because it has been given to them by their creators themselves, creators who self-identify themselves - not infrequently - exactly as pornographers. Therefore, it can be assumed that pornography is that, which its

\footnotetext{
${ }^{2}$ Pioneer of Polish research of popular culture and popularization of its effects.
} 
creators consider and label as pornography. With that assumption made, the unclear and disputable area becomes limited and less significant.

An example of a person who has reached relatively widespread fame and acknowledgement through pornography is a young (born in 1988) actress who goes by the stage name "Sasha Grey". Throughout the first three years of her career (2006 - 2009) she has played in 200 films belonging to different genres of pornography, especially the most hardcore, which are not prohibited by US law. Sasha Grey has starred in a popular talk show hosted by Tyra Banks, she contacts her fans by means of her official website, Myspace profile and Youtube channel. This actress has risen to popularity thanks to pornography; however, she quickly became a part of the world of mainstream popular culture. She has starred in music videos of such bands as The Roots (song: Birthday Girl) and Smashing Pumpkins (Superchrist). Her image has also been featured in the graphic inlay of the latter group's album Zeitgeist. Sasha Grey has posed for such artists as Richard Kern, Terry Richardson, James Jean, David Choe, Frédéric Poincelet and Zak Smith. She starred in an independent film Quit (directed by Dick Rude). She has performed guest vocals on the album Aleph At Hallucinatory Mountain by Current 93 - one of the most important bands in the history of experimental music. She has also founded a music band - ATtelecine - whose debut EP (A Vigillant Carpark) belongs to the industrial music genre. Sasha Grey has played one of the leading characters in The Girlfriend Experience by a famous director: Steven Soderbergh. "Gazeta Wyborcza" (best-selling Polish liberal daily newspaper) when mentioning the film in reference to its screening during the $25^{\text {th }}$ Warsaw Film Festival and covering the character played by Sasha Grey has not even referred to her as a porn star. The article was accompanied by a still showing the leading actress (Felis 2009, p. 17). In interviews and on her Myspace profile Sasha Grey admits to her fascination with key figures of classic cinema, counterculture or modern and postmodern philosophy.

Porn stars have so far become famous celebrities (for instance: Jenna Jameson); however, up till now they have not reached areas so far away from pornography as experimental music, while not abandoning their porn career and even combining those distinct activities. It is yet another step towards a full emancipation of pornography, its departure from the shameful and private domain and entry into the field of popular culture. This emancipation is taking place in the more and more hardcore (but still legal) spheres of 
pornography ${ }^{3}$. What "Playboy" has accomplished for soft-core pornography, young actresses (such as Sasha Grey) are doing for the hardcore genres.

American feminists have discussed changes that occurred in the looks of actresses starring in porn films at the turn of the $21^{\text {st }}$ century. The merit of the discussion was the controversy whether transition from grotesque women with silicone breast implants to the "girl next door" had restored the real appearance of a women's body in pornography. What has been kept aside in the dispute is the fact that a major shift had occurred in the appearance of the most popular actresses, which rather means that an earlier unappreciated genre of film pornography had risen to popularity. One can come across large and small-breasted actresses alike, slim, obese (even pathologically), etc. Pornography has not only become a more and more appreciated and accepted genre of popular culture, it has also split (and is still splitting) into genres specific only to this field.

The separation of pornography from sex, its enormous popularity and autonomy as a medium (as proven by its division into genres) reveal that pornography has reached the final, fourth phase of the image set by J. Baudrillard: "it has no relation to any reality whatsoever; it is its own pure simulacrum" (Baudrillard 1995, p. 6). It can also be assigned to the third of J. Baudrillard's orders of simulacra: "simulacra of simulation, founded on information, the model, the cybernetic game - total operationality, hyperreality, aim of total control" (Baudrillard 1995, p. 118). Pornography's way of accomplishing this ultimate stage was the separation of the image of sex from an actual coitus. Image and sound had been separated from smell and touch associated with sexual intercourse. Then they were transformed into a digital file, a picture or a film set in two dimensions, which can be further manipulated. The growth of the pornographic industry, divided into genres, has given pornography selfsufficiency, the potential of self-reference, allusions which are possible and understood only within it. The expansion of Internet has brought pornography to the furthest parts of the world and ensured its constant progress and popularity. However, there is no real sexual intercourse behind this phenomenon anymore.

As W. Godzic points out, early pornographic films ("stag films" as they used to be called) were not supposed to lead to sexual satisfaction and fulfillment - they were supposed to serve only as a stimulus towards further actions (they were screened usually in brothels and

\footnotetext{
${ }^{3}$ When mentioning legal issues concerning pornography the author refers to the rule of law in the so-called "western" countries (especially countries of North America and Europe). Pornography remains illegal in such countries as India, Belarus or Muslim-dominated states.
} 
at the end of the showing, and captions asked the audience to "take care of the girls"). In those films visual pleasure oscillated between masculine pleasure earned from articulation of the desire of possessing the feminine body and (ever unattainable) identification with the male protagonist (Godzic 1996, p. 72). Currently N. Wolf describes how pornography replaces the realization of sexual needs in the real world. The history of pornography can thus be perceived as registration of the breaking away of meaning and expansion of simulation history of a sign which annihilates the sense which had been primarily attributed to it.

A phenomenon's presence in the world of internet memes can be treated as a determinant of its rooting in postmodern popular culture. The concept of the internet meme originates from the concept of the meme itself which was introduced into academic discourse by R. Dawkins in the famous book Selfish Gene. The meme is a basic unit of cultural evolution analogical to the gene in biological evolution (Dawkins 2006, pp. 189-201). The internet meme has no significance to the evolution of the human species, although it is connected to the growth of the internet itself. It is but an entity (a single image, a sequence of images, a word or a sentence) circulating throughout the world wide web, which - when evoked in an unusual situation or just alluded to - has a predominantly comic effect, understood only by internet users familiar with the associated topic. Just as understanding humor based on the play of words is an evidence of a good knowledge of a foreign language, so is the understanding of internet meme-based humor a symptom of familiarity with the cyberspace.

One of the most popular entertainments of Polish internet users (at the time of writing this paper) is creating, reading and commenting on the so-called "demotivators" - which are parodies of motivators based on sarcasm and black humor, derived from American popular culture. They often allude to current issues or commonly known persons - above all internet memes. Demotivators posted on the most popular Polish website dedicated to this kind of entertainment (Demotywatory.pl) often alluded to one of the sites providing free access to pornographic films - namely RedTube. One of the demotivators featured one of the young generation American porn actresses: Michelle Anne Sinclair (who goes by the stage name "Belladonna"). Other illusions have also appeared to pornography and its viewing, although it is not a main issue covered by Polish demotivators. It must nevertheless be emphasized that they are severely moderated. On the Russian website dedicated to demotivators (Demotivation.ru), where there are no such restrictions, pornography (especially the hardcore type) is one of the most common topics (besides, for instance, anti-Semitism or mockery of 
violence victims). The presence of pornography in internet humor proves that it has become the next element of the communication code of internet users - particularly young ones. And mostly through its simulative character it has been made possible to translate pornography to the internet memes code and include it into the sphere of internet discourse.

\section{Esoteric aspects of pornography}

Prior to discussing the esoteric aspect of pornography we must explain what will be understood as "esoteric" in later parts of the paper. The author uses this term to describe the hidden ${ }^{4}$, deeper aspect of reality (and its enquiry) deriving from its connections to sacrum (the sacred) - an aspect unlike the exoteric, external, deriving from the connections with profanum (the profane). Thus the author departs from the colloquial understanding of esotericism in which this term is used to describe certain occult, spiritualist or magical theories and practices related to the so-called New Age (Eliade 1978, pp. 47-68).

When characterizing the simulative aspect of pornography the author has referred to postmodern and feminist thinkers. When depicting the esoteric aspect I shall also refer to two different discourses. In the preface to the Polish edition of Rudolf Otto's Das Heilige. Über das Irrationale in der Idee des Göttlichen und sein Verhältnis zum Rationalen (The Idea of the Holy) J. Keller states that in the field of religious studies there have always been scholars who deprecated the meaning of myth and religion; among them were A. Comte, L. Feuerbach, M. Müller, J. Frazer, W. Wundt, and S. Freud. Such tendencies have been opposed by those thinkers who demanded the autonomy of religion and myth; those were above all: $\mathrm{F}$. Schleiermacher, R. B. Marret, N. O. Soederblom, R. Otto, M. Eliade and C. G. Jung (Keller 1994, pp. 8-9). And it is the latter discourse of religious studies (appreciating the value of religion and myth) that I will firstly refer. The other discourse that will aid me in characterizing the esoteric aspect of pornography is a school that is described by M. Eliade as traditional Western esotericism (Eliade 1978, pp. 47-68). It is represented mostly by the school of Integral Traditionalism, founded by R. Guénon and J. Evola, and the school of Perennial Philosophy (Sophia perennis) represented by A. Huxley, A. Commaraswamy, F. Schuon and others. The ideas of those two schools are highly analogous to the views of J. R.

\footnotetext{
${ }^{4}$ The esoteric can be hidden not necessarily by a sophisticated system of initiation or an actual personal hierarchy within a secret society. The esoteric perception of reality can be unavailable for an ordinary man only because of its high level of abstraction of the doctrine and the level of knowledge necessary for its understanding. This situation occurs for instance in the case of Hinduism, where the teachings of, for example, the Advaita Vedanta school are not hidden from anyone, however they are difficult to comprehend without solid theoretical background.
} 
R. Tolkien which have been expressed in his novels and private correspondence. The latter of the aforementioned discourses I propose to name "traditionalist". Its exponents are joined exactly by traditionalism ${ }^{5}$, the appreciation of mythic and symbolic thinking and perception of reality, pessimistic historiosophy or the belief in the primacy of spirit over matter. It must be emphasized that traditionalists separate themselves from optimistic spiritism; indeed they condemn it as a pseudo-religion (Eliade 1978, 65-67). Traditionalists do not see an opportunity of world revival without the occurrence of a cataclysm annihilating corrupt reality. They glance into the past, not the future - they invoke Old Age, not New Age.

The two major exponents of the traditionalist school (R. Guénon and J. Evola) have been mocked by Umberto Eco in the novel Foucault's Pendulum (Eco 1989, pp. 141, 202, 421). This author ranks them among charlatans, prattlers and mythomaniacs active from time immemorial. However, another humanities authority can be alleged here: namely M. Eliade, who presents R. Guénon as a representative of traditional esotericism. He discusses R. Guénon's radical criticism of theosophy and other spiritist doctrines, underlining that it has been educed from the traditional esoteric stance (Eliade 1978, pp. 66-68). Argument concerning those characters reveals how controversial they are, concurrently proving that they are known and significant enough to get such recognized scholars as M. Eliade and U. Eco involved in the dispute ${ }^{6}$.

Integral traditionalism implies that there is one, infinite, eternal, unconditioned Absolute. It is identical with the one and everlasting Primordial Tradition. It is based on transcendental principles, with their beginnings incomprehensible. Knowledge of the Primordial Tradition has been transferred to men through Primordial Revelation. It is manifested in various religions and metaphysical systems (for example: Hinduism, Taoism,

\footnotetext{
${ }^{5}$ Traditionalism understood as an actually existing worldview, not attachment to certain customs.

${ }^{6}$ The dispute between M. Eliade and U. Eco may have much deeper causes deriving from the afore-accepted worldviews. Traditionalists attacked such ideas as equality, democracy, humanism, secularization or progress, which seem very close to U. Eco. In this field M. Eliade and his revered appreciation of religion, mythology and archaic perception of reality was much more at home with the traditionalist. The political dimension of this argument must not be forgotten. R. Guénon did not take any side in the contemporary political disputes; however, he never denied considering hierarchical systems of power (theocracy and monarchy) as the best. On the other hand, J. Evola attempted to cooperate with the Italian fascist state and the German national socialist regime. Later on he confessed to considering those attempts as mistakes, nevertheless he criticized those systems from the rightist positions and he never ceased to be a reactionary and the proponent of the restoration of the Roman empire. U. Eco can certainly be considered an exponent of the Italian liberal democratic left, for which J. Evola will always remain a villain of national history. It is yet another feature distancing him from M. Eliade, who during mid-war years sympathized with the Romanian Iron Guard (Garda de Fier) and the Legion Of Archangel Michael (Legiunea Arhanghelul Mihail), and who has later on supported the French New Right (Nouvelle Droite). It is also noteworthy that M. Eliade has co-edited the periodical "Antaios", whose collaborators were among others E. Jünger, exponent of the German conservative revolution, and J. Evola.
} 
Judaism, Christianity, Islam, Roman Catholicism). Separate religions are just variants and alterations of the Primordial Tradition. Each religion has two aspects: exoteric (accessible for the masses) and esoteric (accessible for the few able to comprehend it). Religions (naturally based on affection) are many, but the metaphysical (exclusively intellectual) is one. The metaphysical eludes all definitions, as "to designate" is "to limit". Primordial Tradition can be learned only through pure intellectual intuition (which is a universal, total, infinite and absolute potentiality). One can reach Primordial Tradition through the study of initiate reality, symbols and rituals (the sacred understood as unity transcending all orthodox traditions). Primordial Tradition can manifest itself only through a symbol, since only a symbol can overcome the boundaries of the kingdom of reason. The purpose of human life is the metaphysical realization of one's personality, which means restoration of the primordial state, natural for men (Bartyzel, René-Jean-Marie-Jospeh Guénon).

In integral traditionalism a dualistic vision of the world is strongly emphasized, with the world considered a place of conflict of Tradition (solar, uranic, masculine, elitist, hierarchical, diverse, supertemporal, sacred, immortal, belonging to the metaphysical order "being”) with Anti-tradition (lunar, telluric, feminine, egalitarian, chaotic, uniform, temporal, profane, mortal, belonging to the physical order - "becoming") (Evola 1995, pp.3-6). A result of this conflict is constant involution: progress does not exist. History of the world is the history of a fall - regression, materialization, secularization. In a natural society (founded on the basis of Primordial Revelation) there existed a spiritual, moral and social hierarchy necessary, as higher cannot spring from the lower (Bartyzel, Julius Evola).

G. Dumézil, eminent scholar of Indo-European mythology, mentions the symmetry of good and evil in Zoroastrian beliefs: "the two parties are organized hierarchically, each under a unique command. Their symmetry is even pushed to the extreme: each »good « being, Ahura Mazda as well as the entities who attend him - and in whom the moralized figures of the gods of the three functions of ancient polytheism are reflected - has his own adversary, his »evil« counterpart”(Dumézil 1977, p. 52). An analogous portrayal of the relationship between good and evil can be found in the writings of J.R.R. Tolkien, who shared such perception of reality in regard to the field of both his academic and literary predilections, as well as his conservative worldview and a certain vision of Christianity as a fulfilled myth consonant with the mythologies of Europe. J.R.R. Tolkien perceived evil as a parody of good. He has emphasized its dependent, parasitic character (Cf. Pearce 1998). 
A term essential for understanding postmodern pornography is "pornotopia" (or "pornutopia"). Christian Hansen, Catherine Needham and Bill Nichols state in Pornography, Ethnology and the Discoursse of Power that "pornotopia" is an ideal construct "visited by an ideal spectator. Pornography proposes an ever-renewed and continually satisfied desire; it offers the perpetuation of desire" (Hansen, Needham, Nichols 1991, p. 212). According to the previously established orientation of inquiry I consider pornutopia an anti-traditional equivalent of Paradise, Valhalla or Svarga. A suggestive vision of a supernatural place of eternal bliss has been presented by the Japanese writer Y. Mishima in his story The Priest of Shiga Temple and His Love which refers to the beliefs of the Buddhist school of Pure Land: "in that Land the earth is made of emerald and the roads that lead across it are lined with cordons of gold rope. The surface is endlessly leveled and there are no boundaries. Within each of the sacred Precincts are fifty thousand million halls and towers wrought of gold, silver, lapis lazuli, crystal, coral, agate, and pearls; and wondrous garments are spread out on all the jeweled daises. Within the halls and above the towers a multitude of angels are forever playing sacred music and singing paeans of praise to the Tathagata Buddha. In the gardens that surround the halls and the towers and the cloisters are great gold and emerald ponds where the faithful may perform their ablutions; and the gold ponds are lined with silver sand, and the emerald ponds are lined with crystal sand. The ponds are covered with lotus plants which sparkle in variegated colors and, as the breeze wafts over the surface of the water, magnificent lights crisscross in all directions. [...] The air is full of jeweled cords, and from these cords hang the myriad treasure bells which forever ring out the Supreme Law of Buddha; and strange musical instruments, which play by themselves without ever being touched, also stretch far into the pellucid sky. If one feels like having something to eat, there automatically appears before one's eyes a seven-jeweled table on whose shining surface rest seven-jeweled bowls heaped high with choicest delicacies. But there is no need to pick-up these viands and put them in one's mouth. All that is necessary is to look at their inviting colors and enjoy their aroma: thereby the stomach is filled and the body nourished, while one remains oneself spiritually and physically pure" (Mishima 1966, pp. 59-60). In Valhalla, warriors who died with sword in hand are awaited by Valkyries - supernatural virgins, who conduct them to a feast, during which they sit beside the Gods. Meanwhile in the pornutopia a random internet user is awaited by countless numbers of diverse men and women ever ready for sex, prepared to satisfy his farfetched cravings. Instead of (referring to the terminology of Swami Prabhupada's writings) a "transcendental pastime" (Swami Prabhupada, p. 773) one 
encounters an extremely un-traditional pastime. However, it does not originate from the material order, but from the simulative and, hence, the anti-symbolic.

In pornography one can then notice anti-traditional inversions of phenomena known from the traditional world. The consumption of sperm, common in porn films, can be related to its ritual treatment by certain Tantric and Shaivist sects as well as the Gnostic Phibonites (Eliade 1978, pp. 93-118), the close-ups of the vagina to its sacred images common in the Classical (vulva), Dharmic (yoni) or Black Africa cultures (Kowalski 1990, pp. 154-159), the consumption of excrement to the Medieval belief in its magical powers or the alchemical conviction of its mysterious sense (Kadmon, Skatologia czyli czarna sztuka), actors (actresses) bearing both male and female physical features (so called trannies or she-males) as hermaphroditical inversions of the traditional androgyne (Cf. Eliade 1965). Through these phenomena the counter-initiative character of pornography is expressed. Their presence in postmodern pornography can be explained by a process to which J. Evola referred as "the involution of the world", the effect of victories of the forces of Anti-tradition, and what M. Eliade called degradation of symbol, degeneration of hierophany: for when mind is no longer able to attain the metaphysical meaning of a symbol, the symbol is becoming understood on more and more vulgar levels (Cf. Eliade 1965).

In reference to the actions portrayed in postmodern pornography such terms as "beastly" or "animal" have been commonly used. One of the major ethologists, Vitus B. Dröscher, claims that animals do not experience satisfaction (in the human sense) from undertaking such actions as eating or sexual intercourse and because of that they cannot become addicted or obese without the intervention of men (Cf. Dröscher 1979). Those reflections supported by the achievements of contemporary ethology confirm certain premonitions and observations of a prominent and controversial $19^{\text {th }}$ century researcher of sex, gender and sexuality, namely: Otto Weininger. In his opus magnum Geschlecht und Charakter (Sex and Character) O. Weininger determines two fundamental types of female character: the mother and the prostitute. For the former the purpose is to have children, for the latter: sexual intercourse with men. And it is the mother which O. Weininger claims to be close to the animal world and by this condition amoral, incapable of morality. The prostitute is immoral and depraved and through this closer to the human condition (Weininger 2005, pp. 188-209). Thus, the character of pornography is not beastly nor animal, but (referring to the Christian nomenclature) demonic. The Bhagavad-Gita mentions two separate and opposite qualities: the divine (of the "Devas") and the demonic (of the "Asuras"). Both transcend the 
human condition; however, the former enables ascension (and that is: initiation), while the latter enables descent into darkness (counter-initiation) (The Bhavad-Gita 1885, $16^{\text {th }}$ chapter). And so pornography, with its relocating of the spectator into pornotopia, has a character "of the Asuras": demonic and counter-initiative.

In one of the scriptures of Tantric Buddhism an ideal partner is described as the best of women, coming from a spiritual family. She neither menstruates nor produces an unpleasant smell, she is never ill and when overcome by sexual desire she knows no shame nor boundaries (Hinduskie wiersze mitosne 2006, p. 76). Women portrayed in pornography meet most of those requirements and this state is achieved exactly by the simulative character of postmodern pornography. Nevertheless, it must be emphasized that contrary to Tantric practices pornography does not lead one to liberation from the samsara.

A concept essential for the comprehension of the esoteric aspect of pornography is "the left hand path". J. Evola writes of a left hand path belonging to the world of Tradition: "that includes breaking the law, destruction, and orgiastic experience of various forms, but starting from a positive, sacred and sacrificial orientation, towards what is above, towards transcendence of all limitation" (Evola, Youth, Beats and Right-Wing Anarchists). Examples of the left hand path can be the various Tantric practices or one of the many Hindu ascetic sects (sadhus), namely: the aghori, whose members consume alcohol, meat or excrements. Pornography can be considered as the left hand path of the anti-traditional world - referring to certain commonly unaccepted practices, but going in the same direction as the right hand path.

Following the once assumed orientation (perceiving evil as a parody of good, interpreting the world's history as strife between Tradition and Anti-tradition, cosmos and chaos) it can be concluded that simulacrum, a term fundamental in describing and understanding postmodern culture and mentality, should have its counterpart in the traditional order. According to R. Guénon, a term which organizes the world of Tradition is the symbol. As this scholar claims, Primordial Tradition can manifest itself only through a symbol, since only a symbol can overcome the boundaries of the kingdom of reason (Bartyzel, René-JeanMarie-Jospeh Guénon). Thus, simulacrum is the anti-traditional counterpart of symbol, pornography a parody of the left hand path, which in the pornotopia leads the postmodern man to counter-initiation and a descent into lower states of being.

\section{Recapitulation}


The postulate of W. Godzic, which has been referred to at the beginning of this paper, is consonant with a fragment of T. Gabiś's Manif(i)esty postkonserwatywne (Postconservative manif(i)estos). T. Gabiś claims that "a post-conservative loves intellectual bricolage: he reads Evola read by Derrida and Derrida read by Evola, Foucault by Szasz and Szasz by Foucault, Gehlen by Bauman and Bauman by Gehlen, Rorty by Schmitt and Schmitt by Rorty, Dugin by Dunin and Dunin by Dugin, Baudrillard by Koneczny and Koneczny by Baudrillard, Chesterton by Vattimo and Vattimo by Chesterton, father Bocheński by Cioran and Cioran by father Bocheński [...]. And so he sails deep, troubled and billowy waters of narration, idea, concepts, esthetics and rhetorics, letting them illuminate each other and expose defects and illusions, he watches with attention and satisfaction how they cast suspicions on each other, debunk one another, jump to each other's throats, bite, weaken and bleed. And he finds something for himself on the battlefield and collects it in his shed"7 (Gabiś 2009). However, in the case of this paper it would be more appropriate to talk of reading Baudrillard read by Evola and Evola by Baudrillard, Wolf by Guénon and Guénon by Wolf etc.

The attempt at finding common ground for postmodernism and traditionalism may seem a risky enterprise. Its validation can be achieved by evoking a concept of the conservative school: "the schism of being". It implies the separation of the world of eternal ideas and the empirically experienced world; the lasting separation of the sacred from the profane. From this perspective the traditionalist and the postmodernist discourses can be considered complementary: the former necessary for the description and comprehension of the sacred aspect of reality, symbol and symbolism, the latter indispensable for the description and comprehension of the profane aspect of reality, simulacra and simulation. Noteworthy is also A. Dugin's concept of "post-postmodernism", whose attempt at creating this kind of synthesis has found a response among Russian opinion-forming circles and state elite.

The interpretation of postmodern popular culture phenomena from a religious and mythological perspective may seem an attempt just as unusually daring. However, it must be recalled how fruitful the appreciation of religious and mythological aspects turned out to be in case of psychology (Carl Gustav Jung), religious studies (M. Eliade), literature (J.R.R. Tolkien) or geopolitics (A. Dugin).

Appealing to the postmodernist perspective is helpful when describing and understanding the phenomenon of global postmodern pornography, it does not, however, answer the question of the future course of events. Actually, the only answer that one can

\footnotetext{
${ }^{7}$ All translations by the author unless stated otherwise.
} 
come up with, referring especially to the concept of simulation, is the prognosis of further realization of the simulative character of pornography. Nevertheless, it is an answer that relates to only a relatively brief progress of events. In reference to the ultimate matters much more information can be found in the works of the traditionalists. They postulate a return to the cyclical concept of time: successive Classical ages or Yugas of Hinduism. It is an apparently extremely pessimistic perspective - the presupposing of the inevitable collapse of the world, downfall and progressing decay. However, this point of view is optimistic concerning the distant future. According to traditionalists, the involution of the world leads to its destruction by the Absolute in the climax of decline and then the return of the Golden Age (Hindu Satya Yuga). A. Dugin writes about the illusion of post-history, the end of time, which only seemingly is an everlasting state - ultimately it will be engulfed by the void which it has evoked. "Everything has an end. It is an end ultimate by itself. Once and for all. And out goes the screen of hallucination known as the contemporary world. And crumble to dust the corpses of TV-viewers, stocks, police stations, scrupulous politicians in their suits, Scrudge geezers from the Trilalatteral Comission and Chase Manhattan Bank, mad scientist with the cloned Dolly sheep, colorful magazines with suntanned girls on the beach and cunningly-eyed pervert designers of the »New World Order«. A black night is coming soundlessly and irrevocably. There is no doubt about it. Whatever tricks time may use at the threshold of mystery - the real ultimate end, not its false simulacrum; with a hard hand this chronological serpent shall be grasped by its slippery neck and flat head. And this head with the venomous sting will be twisted and wrenched away. Wann endet die Zeit? Gott weiß es. Gott weiß es. Gott allein weiß es. But there is moment, there is time, there is the beat of a heart and the jingle of a star when it eventually occurs. A black, black night” (Dugin, Пост Модерн?).

\section{Bibliography:}

Baudrillard J. (1995), Simulacra and Simulation, Glaser S. F. (trans.), University of Michigan Press, Michigan.

Dawkins R. (2006), The Selfish Gene: $30^{\text {th }}$ Anniversary Edition, Oxford University Press, Oxford, New York.

Dröscher V. B. (1979), Überlebensformel- Wie Tiere Umweltgefahren meistern, ECON, Düsseldorf.

Dumézil G. (1977), Gods of the Ancient Northmen, Lindow J. (trans.), A. Thoth, F. Charat, G. Gopen, University of California Press, Berkeley, Los Angeles. 
Eco U. (1989), Foucault's Pendulum, trans. W. Weaver, Secker \& Warburg, London.

Eliade M. (1978), Occultism, Witchcraft and Cultural Fashions: Essays in Comparative Religions, trans. University of Chicago Press, Chicago.

Eliade M. (1965), Mephistopheles and the Androgyne; Studies in Religious Myth and Symbol, trans. J. M. Cohen, Sheed and Ward, New York.

Evola J. (1995), Revolt Against the Modern Word, trans. G. Stucco, Inner Traditions, Rochester.

Felis P. T. (2009), WFF 13. Festiwal świata, „Gazeta Wyborcza”, 8. 10. 2009.

Godzic W. (1996), Oglądanie i inne przyjemności kultury popularnej, Universitas, Kraków. Hinduskie wiersze miłosne (2006), Miniatura, Kraków.

Hansen Ch., Needham C., Nichols B. (1991), Pornography, Ethnology and the Discourses of Power, [in:] Nichols B. (1991), Representing Reality: Issues and Concepts in Documentary, Indiana University Press, Bloomington.

Keller J. (1993), Rudolf Otto i jego filozofia religii, [in:] Otto R. (1993), Świętość. Elementy irracjonalne w pojęciu bóstwa i ich stosunek do elementów racjonalnych, Kupis B. (trans.), Thesaurus Press, Wrocław.

Kowalski K. (1990), Eros i kostucha, Ludowa Spółdzielnia Wydawnicza, Warszawa. Mishima Y. (1966), The Priest of Shiga Temple and His Love, Morris I. (trans.), [in:] Mishima Y. (1966), Death in Midsummer and Other Stories, New Directions Publishing Corporation, New York.

Mishima Y. (1966), Death in Midsummer and Other Stories, New Directions Publishing Corporation, New York.

Nichols B. (1991), Representing Reality: Issues and Concepts in Documentary, Indiana University Press, Bloomington.

Otto R. (1993), Świętość. Elementy irracjonalne w pojęciu bóstwa i ich stosunek do elementów racjonalnych, trans. B. Kupis, Thesaurus Press, Wrocław.

Pearce J. (1998), Tolkien: Man and Myth, HarperCollins, London.

Swami Prabhupada, Bhagavad-gìtā as it is: Second Edition, Bhaktivedanta Book Trust.

Toeplitz K. T. (1975), Kultura w stylu blue jeans, Państwowy Instytut Wydawniczy, Warszawa.

Weininger O. (2005), Sex and Character: An Investigation Of Fundamental Principles, Löb L. (trans.), Indiana University Press, Bloomington. 


\section{Netography:}

Bartyzel J., Julius Evola, http://www.legitymizm.org/ebp-julius-evola, retrieved: 20. 04. 2010.

Bartyzel J., René-Jean-Marie-Jospeh Guénon, http://www.legitymizm.org/ebp-rene-jeanmarie-joseph-guenon, retrieved: 20. 04. 2010.

Dugin A., Пост Модерн?, „Elementy” 9, http://lib.rus.ec/b/195209/read\#t6, retrieved: 10. 04. 2010.

Evola J. (2007), Youth, Beats and Right-Wing Anarchists, http://thompkins_cariou.tripod.com/id99.html, retrieved: 9. 11. 2009.

Gabiś T. (2009), Manif(i)esta postkonserwatywna, http://www.tomaszgabis.pl/?p=93, retrieved: 12. 10. 2009.

Kadmon, Skatologia czyli czarna sztuka, Misiuna D. (trans.), http://okultura.pl/texts/novum/005.php, retrieved: 10. 11. 2009.

Wolf N. (2003), The Porn Myth, http://nymag.com/nymetro/news/trends/n_9437/, retrieved: 9. 09. 2009.

The Bhagavad-Gita (1885), Arnold E. (trans.), http://www.sacredtexts.com/hin/gita/index.htm, retrieved: 3. 05. 2010.

Yawar A. (2006), The End of Sex? Pornography is changing the nature of physical affection, http://english.ohmynews.com/articleview/article_view.asp?at_code=327327, retrieved: 5. 11 . 2009. 